\title{
The Evaluation of Cultural Identity by the Preservation of the Historical Heritage of Saint George in Mondonico
}

Francesca Andrulli Chiara Bonaiti ${ }^{\star \star}$ Alessia Silvetti ${ }^{\star \star \star}$

\section{Abstract}

The knowledge of the location, history and current state of conservation of historic built landscape is the best way to warrant its protection. We can only pass on to the next generations what we know and recognize as worthy and representative of our memory, improving the quality of life. Conservation of the architectural heritage is an opportunity to increase the economic resources also: "the historic buildings are a resource because they can satisfy new uses, compatible with their exiting features, that brings income and social advantages" (Della Torre, 2010). The organizations for designers' training have a main role to suggest the right approach to reuse historical buildings. We don't have to adhere to the common practice of simple renovations, refurbishments that deeply distort the entity and the environment in which it has been for hundreds of years. The case study of Saint George in Mondonico, is an example of that phase of the conservation process that deals with a profound knowledge of all the features of the buildings with the aim to discover and display the value.

We can understand and decide the minimal conservative restoration interventions thanks to material and state of conservation of the building's surveys and the detailed analysis through historical research
Keywords: Ancient village, diagnostics, minimum intervention, compatibility, authenticity.

*Tutor at the School of Building Architecture and Engineering, Politecnico di Milano, Italy. E-mail: francesca.andrulli@mail.polimi.it Orcid ID: http://orcid.org/0000-0002-71534603

**Tutor at the School of Building Architecture and Engineering, Politecnico di Milano, Italy. E-mail: chiara.bonaiti@mail.polimi.it Orcid ID: http://orcid.org/0000-0002-79526114

***Adjunct professor at the School of Building Architecture and Engineering, Politecnico di Milano, Italy.

E-mail: alessia.silvetti@polimi.it Orcid ID: http://orcid.org/0000-0002-42836274 
needed to identify the construction phases and the interactions with the surrounding territory.

Only this way we can clearly understand and use the remaining potentialities of the building and its surrounding. The valorisation of its potentiality is fundamental for the awareness of the value of the historic heritage for the local community that produced the objects in the past, and that has the duty to protect the remains, although if not always in a conscious way.

\section{INTRODUCTION}

The project of preservation and valorisation of the built heritage in Mondonico, an ancient village of Dorio municipality (Northern Italy, Lecco lake area), is an example of diffusing knowledge, protection of the Cultural heritage.

Figure 1. Mondonico from an aerial view

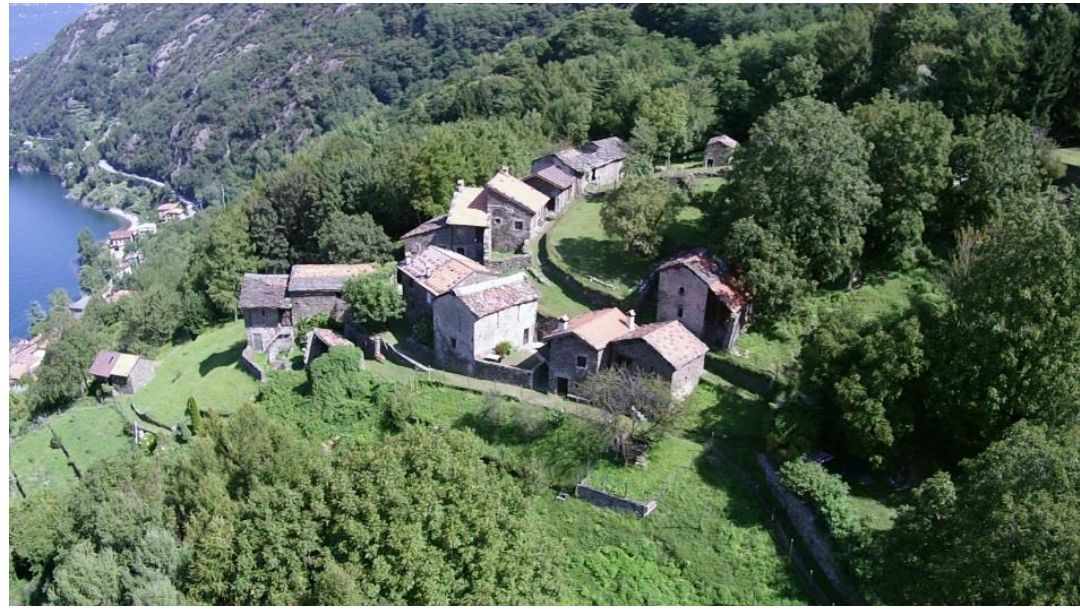

The methodology bases on the multidisciplinary analysis of the site, performed both within an international workshop of Politecnico di Milano and Ball State University (march 2014) and the studio of the Restoration course at Politecnico. The aim is to give an example of protection of the Italian historic built landscape (Rosina, 2017), particularly focusing on the preservation of Saint George Church in Mondonico.

Despite it is not being a monument, the church strongly characterizes the site and it is linked to the historic village of Mondonico and Dorio, by means of the physical connections (roads and pathways) and intangible connections, because it remains a reference for the local community at present as it was in the past. It is an example of the perseverance of the cultural values of the community at present.

The project of valorisation of the village and the church, therefore, starts with the project of preservation of the buildings; in the 
present paper, the authors report the main steps and achievements of the project on the church.

The intervention requires to achieve the acknowledgement of the values that persist in the building, also to strengthen and display the discovered values (Cavada, 2002).

'Restoration is the methodological moment of recognition of the work of art, in its physical consistency and in its dual aesthetic and historical polarity, with a view to its transmission to the future.' Cesare Brandi, 1977, Theory of restoration, second edition

The first step of the knowledge; the historic-critical documentation, the recognition of the existing and possible future functions, of the spaces is pivotal for the next step of the intervention. In the present Italian debate on restoration, the focus on the mandatory documentation is well defined by Amedeo Bellini, the founder of the Specialization School of Architecture Preservation at Politecnico di Milano: "We can preserve only what we know, the first question is: what preserve and not how to preserve in the conservative restoration - (Bellini,1994).

The coordinated use of the information coming from the archives, iconography, texts and the assessment/survey of the building is the effective tool to recognize the features of a historic building in a technical data organization, that has the aim to scientifically support the restoration. The comprehension of these steps is due to a constant, recurrent observation of the building, its materials and its environment: "any intervention on the historic building requires a preliminary, prolonged, accurate process of knowledge, because only going beyond the appearance and comprehending the inner and hidden structure of architecture is possible to lead the conservation activities" (Docci, 1999) and the most respectful and successful project for the new use. In fact, the documentation and assessment allows to know the potentiality of the building, lead the choices of the transformation for the new use with the highest respect for its features. The "education to restoration and conservation, substantially the education to listen the building (COTAC, Understanding Conservation, UK) is associated to the leading criteria for the intervention: compatibility, reversibility, least intervention and recognition (Mileto, Vegas, 2011).

\section{THE KNOWLEDGE}

\section{History}

The historic documentation of Saint George church included the research in the parish, state archives and the libraries about the 
historic and cultural background, the building typology and techniques, the history of modification and intervention.

Dorio is one of the Como Lake's villages and it's set along three horizontal orographic lines. Upstream there is the ancient village Mondonico. Over time the inhabitants moved downstream close to driveway and lake.

Figure 2. Mondonico: an ancient village on the side of Lecco lake
Figure 3. Mondonico: the masterplan of the village

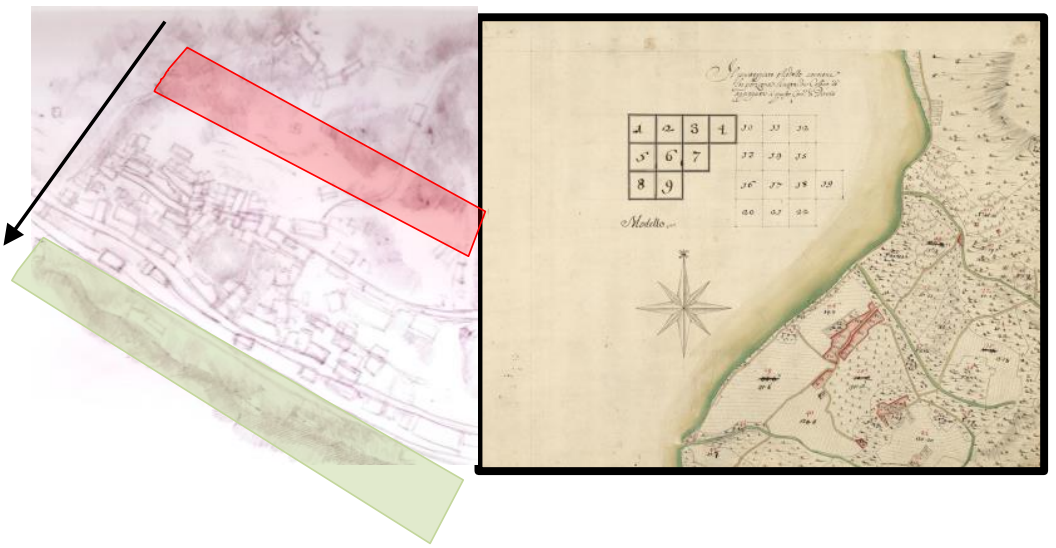

In Mondonico village, at the southern edge of the urban blocks, a small white church and its bell tower rise on the top of a small hill, close to the Mills valley.

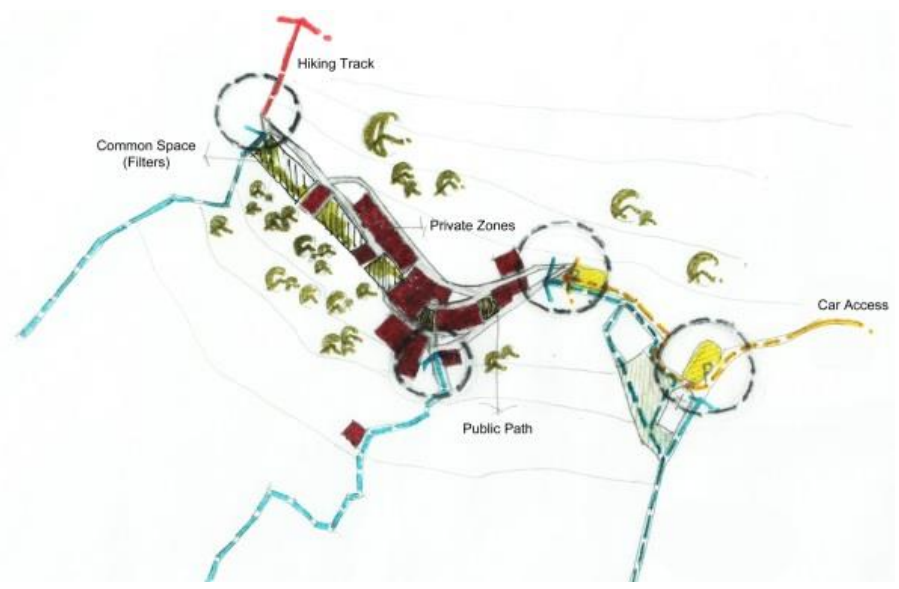

It is the first church built in Mondonico community. It is dedicated to the warrior martyr Saint George, a dedication very popular in the area. The inhabitants set the church in a sacred area separated from other buildings, instead of building the church in the middle of the other housing and farming constructions. Near the church, in the past, up to the 19th century, there was a cemetery. The church entrance has its orientation towards west, according to the tradition. The churchyard lies on an artificial terrace, on an upper level from the natural slope of the hill, supported by a constraining stone dry wall. 
The courtyard has a double function: to create a respectful area in front of the church and build the base of the façade, together with the stairs on the side.

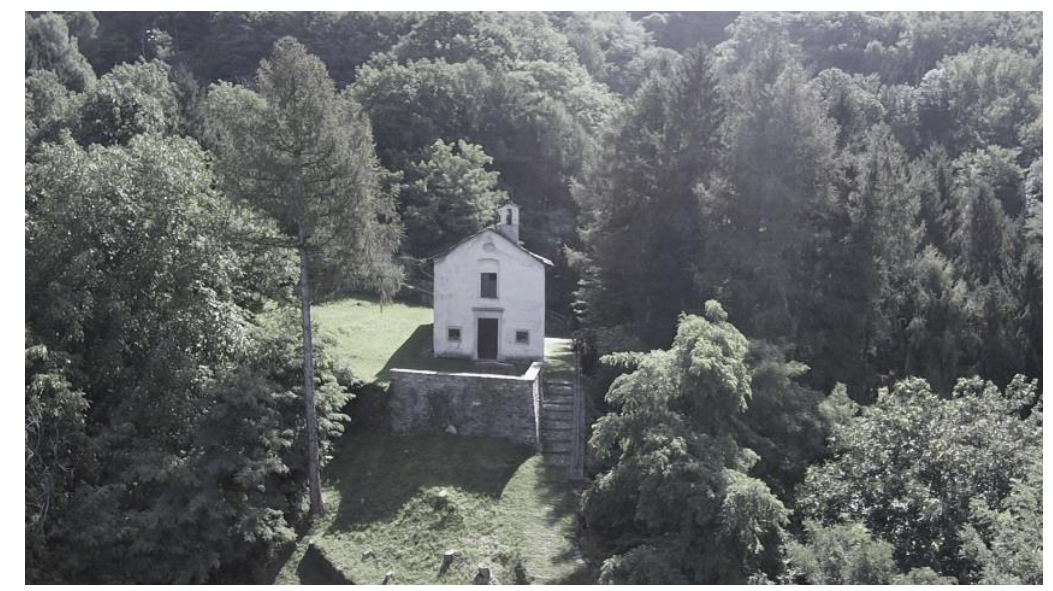

The first documentation of the church dates back to 1412; the description mentions a porch in front of the church for public meetings before religious functions. In 1506, the church of Saint George in Mondonico became an autonomous parish, due to the fervent request of Dorio and Mondonico's population that could not reach Dervio church during the winter. (ACAM) Saint George remained a parish until 1677, when the title passed to the new church of Holy Virgin Mary in Dorio, where most of the inhabitants had relocated to in the meantime.

The report after the pastoral visit of cardinal Ferrari, in 1905, refers that the ancient and small church of Mondonico was enlarged in the 16th century, the original date is unknown: "Saint George is an ancient church. It's unmemorable and her origin is unknown. It was increased in 1500, it's small. Now the church is unused. But there isn't the bell that must be set by the municipality, that doesn't give any response". (ACAM)

To quote Andreani's description (Andreani,1898), the building underwent numerous modifications over the passage of time. The present structure mainly dates back to the 16th century and partially to the second half of 17 th century.

Furthermore, in 1804 other variations to the façade were made. In fact, the small windows (with iron grids and stone frames) were opened during the counter-reformation time to allow the population to pray looking at the Eucharist although the church was closed. The doorframe dates to the beginning of the 17 th century. The small nave is $5 \mathrm{~m}$ wide and $12.5 \mathrm{~m}$ long, it has a flat ceiling, whilst a barrel vault covers the presbytery. The apse is a semi-circle, and this is the most ancient remains of the previous church: the masonry does not fit with the dimensions and axis of
Figure 4. The church of Saint George in Mondonico, aerial view 
the nave (as it is a little larger) and it was 'pasted' on a new construction.

In the past, frescoes should have had decorations on the interior plasters; now the only one is the painting ( $\mathrm{cm} .352 \times 297$ ) on the northern side, dating back to the 15th century. It has six framed pictures that represent leaves, branches and small rounded decoration. The dates of the painting are on the bottom: 1492 and 1497.

\section{Material analysis}

The survey on field is the second step towards knowledge.

Material identification is important to understand the historical and cultural value of the church. The analysis was supported by a study upon traditional building techniques used when the church was built. The facades' analysis highlighted these materials:

- Local stone;

- Rough plaster as finishing material (civil plaster just on the main façade);

- Cement mortar for the basement part of the building;

- Granite for details: windowsills and doorsteps;

- Lime and cement mortars as patches on the walls;

- Iron for drainpipes and eaves;

- Wood for the entrance door and a window on the north side;

- Lombard cotto overlapped by Italian 'piode' made by local stone for the roof.

Inside the church, the main materials are granite and Lombard cotto for the floor and civil plaster on internal walls. The altar was of marble.

Figure 5. North-West elevation: an example of surface mapping of materials

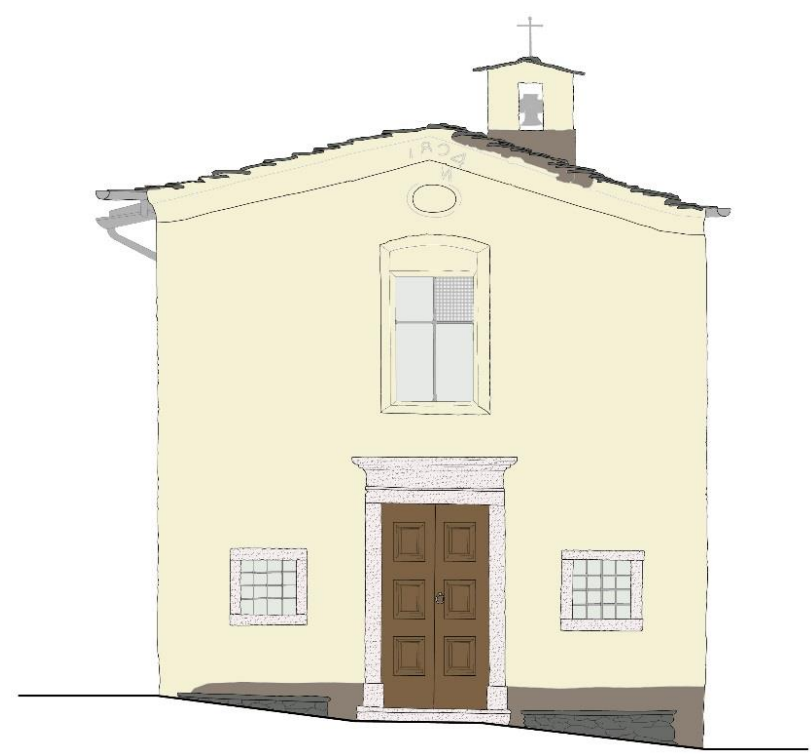




\section{Diagnostics and degradation analysis}

After an initial visual evaluation, the following hypothesis was proposed: “Lake Como's climatic context, in combination with the microclimatic conditions of Mondonico, is the cause of surface damages including erosion, biological attack and overall degradation". The deterioration survey has the aim of listing building's damages and make theories upon the possible reasons that produced a particular pathology, that the diagnostic analysis later confirms or rejects.

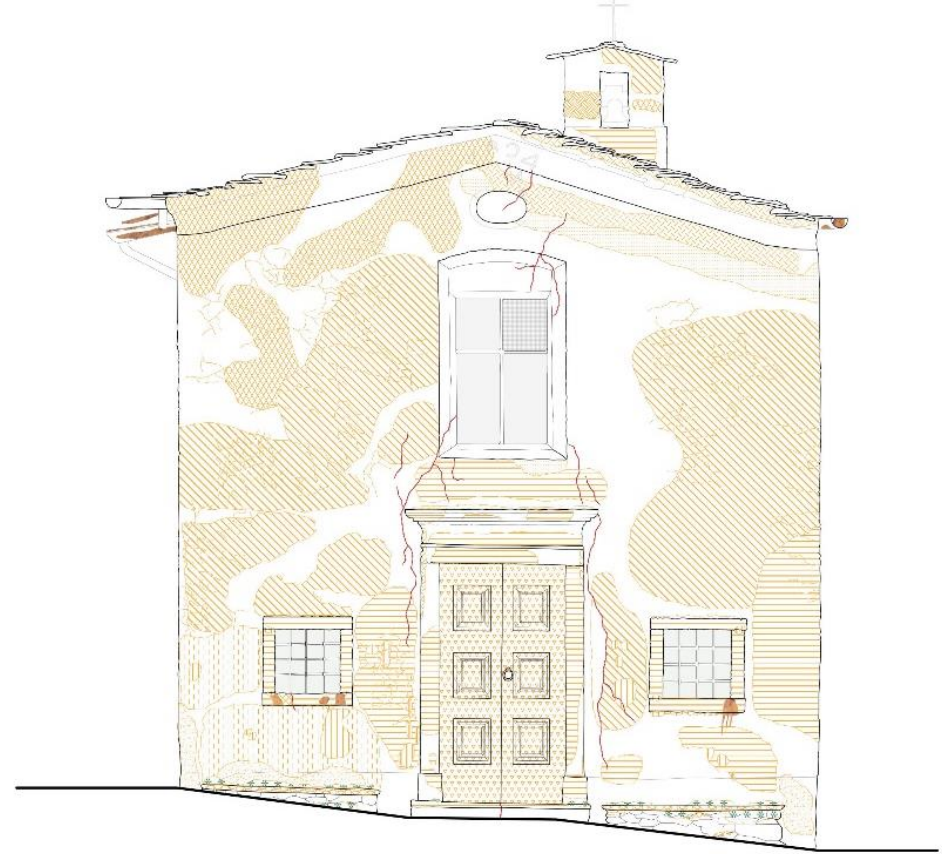

Two different methods were used to identify damages and possible causes: infrared thermography and psychrometric analysis.

Infrared thermography is a non-destructive method of analysis and diagnosis of historical buildings. By means of this method, it's possible to identify presence of humidity, previous openings of doors and windows, structural systems covered by layers of plaster and walls that have been demolished. Diagnostics is also used to detect the entity of wall's cracks to highlight the passthrough ones and to identify the parts affected by detachment phenomenon.

An infrared camera displays images with different color gradations that show surface temperatures. Each material has a different thermal capacity, this is the reason why are able to observe the differences between the high temperature of window frames made by granite and the low temperature of plaster in the thermal images. To analyze the main façade (on the north-west side): the right portion is partially shaded by trees, so it has a
Figure 6. North-West elevation: an example of surface mapping of damages 
lower temperature, while the left part is completely exposed to sunrays and it has a higher temperature. In the right portion, from the basement level to the windowsill, the temperature is quite low $\left(15^{\circ} \mathrm{C}\right)$ compared with the rest of the façade; this can be suggestive of the presence of upwelling humidity with consequent phenomena of biological patina and plaster detachment. In the right upper part, there's another low temperature zone $\left(15,5^{\circ} \mathrm{C}\right)$, which can be explained by the presence of water's seepage from the roof.

In the left portion, which is warmer, the basement part has a higher temperature $\left(20,5-22^{\circ} \mathrm{C}\right)$; this is the typical effect produced by a plaster detachment, and this hypothesis is confirmed by the dull sound produced by knocking on the wall. There are some sporadic thermal gradients irregularly distributed along the entire façade; this is the effect of an uprising micro-cracking phenomenon and possible erosion.

Figure 7. North-West elevation: an example of application of infrared thermography

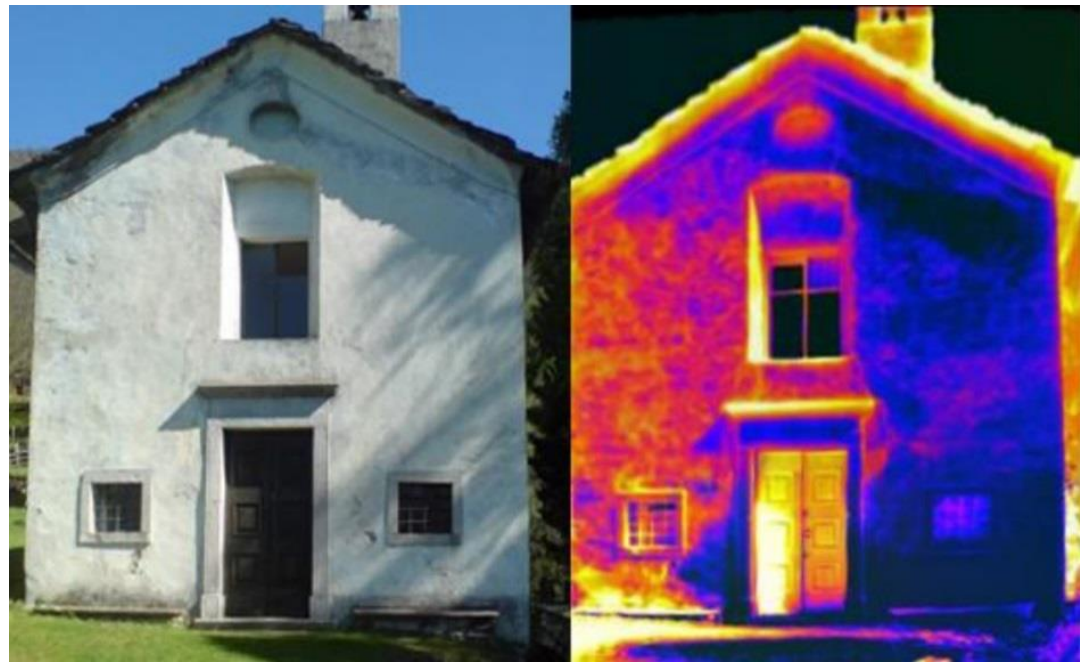

Another diagnostic method is the psychrometric analysis that gives a measurement of humidity and temperature. It's possible to understand the movement of air inside the building and from the interior to the exterior and vice versa. The greater the difference between the dry and wet temperature is, the lower the relative humidity is. When humidity is high, the stress on the building's envelope increases and the amount of damages is bigger. Taking measures in different points inside the church allows to understand where the warmest points are and where the humidity is concentrated. In the left portion, which is warmer, the basement part has a higher temperature $\left(20,5-22^{\circ} \mathrm{C}\right)$; this is the typical effect produced by a plaster detachment, and this hypothesis is confirmed by the dull sound produced by knocking on the wall. There are some sporadic thermal gradients irregularly distributed along the entire façade; this is the effect of an uprising micro-cracking phenomenon and possible erosion. 
Another diagnostic method is the psychrometric analysis that gives a measurement of humidity and temperature. It's possible to understand the movement of air inside the building and from the interior to the exterior and vice versa. The greater the difference between the dry and wet temperature is, the lower the relative humidity is. When humidity is high, the stress on the building's envelope increases and the amount of damages is bigger. Taking measures in different points inside the church allows to understand where the warmest points are and where the humidity is concentrated.
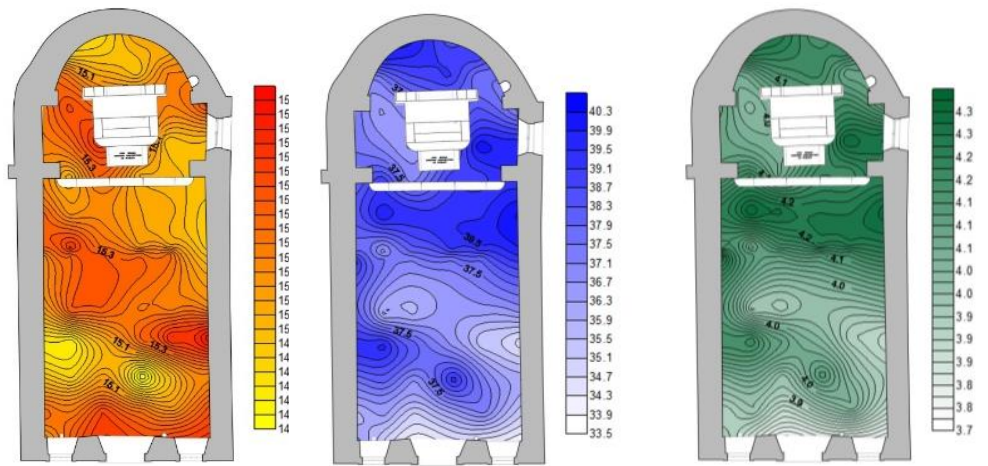

The temperature data indicate that the eastern side of the apse is the warmest area inside the church because of the constant sunlight hitting this façade. The maximum amount of moisture was found in north and south facades, probably due to the lack of sunlight received.

The relative humidity data yield good results. The spread of humidity is relatively homogeneous and doesn't have any high concentration in a specific point. Data from specific humidity is similar to the relative humidity data.

Finally, after all the analyses, it can be said that the infiltration of water and moisture found in some points is linked to the phenomenon of capillary rise, leading to the formation of biological patina and mold. From a structural perspective, there is a possibility of failure at the foundations as observed from the cracks on the floor and on the main façade.

The structural cracking ensued the worst damage, probably due to the location (on a steep slope) and the soil. Without a rigorous monitoring of the cracks, it is not possible to design an appropriate intervention. It is strongly recommended to start structural monitoring, as soon as possible, with the aim to obtain the necessary data at least for the application of provisional strengthening that could prevent further damages.

The church suffers from a of lack of maintenance or inadequate maintenance intervention, in fact the most coverage of damages
Figure 8. Psychrometric analysis: maps of temperature, relative humidity and specific humidity 
on the surfaces result in superficial deposit, discoloration and biological patina.

The final objective of surface mapping and diagnostics analysis is to individualize the most appropriate interventions for the building. Every building is unique and it's necessary to conserve it in its authenticity. The intervention solutions must be focused on the specific case, they can't be general and repetitive. Nowadays there's a development of a sense of responsibility towards the identity of our monuments.

\section{INTERVENTION OF CONSERVATION}

\section{Intervention's keywords}

To get an ideal architectural design from the perspective of conservation it is imperative to follow five basic keywords:

- MINIMUM INTERVENTION

- REVERSIBILITY

- PHYSICAL AND CHEMICAL COMPATIBILITY

- DISTINCTNESS

- AUTHENICITY

This is exactly what has been done in this case.

The minimum intervention consists of repairing compromised or missing elements but also in the design of lines, shapes, developments and volumes, which, if missing, make the architectural image incomplete. The strength of a good restorer is the ability to stop the project before intervention becomes invasive.

The concept can be summed up with the maxim:

'The restoration ends when the hypotheses start'.

Another sentence best describes the second keyword:

'Reversible changes should be considered temporary. Nonreversible change should only be used as a last resort and should not prevent future conservation action' - (Burra Charter, 1979)

According to the philosophy of reversibility, an intervention can later be removed as if the intervention had never occurred, leaving no indelible harm to the asset. Those changes, where possible, any permanent harm to the historical significance of the building fabric or the use of the building are to be avoided. It is an interesting perspective to see us as custodians of the 
historic buildings we inherit and it is our responsibility to maintain them, and often to develop them, for the enjoyment of future generations.

It's clear that in order to carry out a proper conservative intervention conducted with compatible techniques, it is necessary to know the physical properties of the materials in situ and their current state of conservation. In this way, you can associate the best materials for consolidation.

Authenticity is the most important keyword, because somehow it includes all the others, if respected it helps to avoid the label of 'historical fake'.

The minimal intervention, the simplification of the silhouettes, the reconcilability, without exaggeration, the use of modern materials and constructions, the opening up to the technological contribution of the various sciences applied are the acquired criteria that must guide the design of the distinctiveness of the 'repairs'.

'The good restoration can be called a drowning of itself in the face of the past. The more the artist today bows, kneels, gets married against the monument, the better he performs his own.' - (Boito,

\section{Proposed interventions}

'The architect in charge of restoration must be a skilled and knowledgeable builder not only from a general point of view, but from a particular point of view, must know the constructive processes adopted in the different eras of our art and in the different schools.' - Viollet Le Duc

In order to fix the problems, found during the diagnostic analyses, the following interventions are proposed:

To avoid the problem of the instability of the old shallow foundations to respond adequately to the loads and stresses transmitted from the building, the designer can prepare different principals. The static improvement of the foundations can take
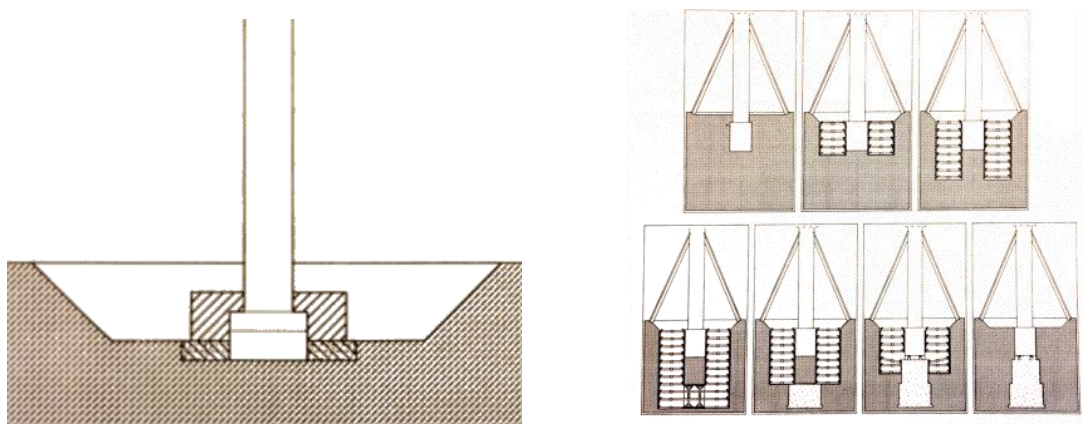

Figure 9. Consolidation backdrop with tiling bead and underpinning masonry (Carbonara, 1996) 
place through the addition of elements in reinforced concrete that can be placed beside or below them.

Normally, you create works that increase the support section alongside the existing foundations with new structural elements connecting them closely with the original foundation walls. These interventions are not very invasive due to needless temporary works and limited excavation depth $(50-100 \mathrm{~cm})$.

This first hypothesis of intervention is to be excluded in our case study in view of the impossibility of engagement of the support elements to the original foundations stone.

In our case, we must recourse to underpinning placed at greater depth so that the original foundations may rest on the new structural elements without the need for fasteners. Another method of intervention to strengthen the foundations is the use of an underpinning piles or micro-piles. We resort to these solutions only in special cases of the presence of water or land very soft requiring high excavation depth. For the case under consideration this is a method too invasive, expensive and unnecessary (Carbonara, 1996). To understand the magnitude and evolution of all the cracks we need a careful periodic monitoring. With more accurate information, we can proceed to implement targeted interventions.

Figure 10. A simple and cheap tool for monitoring cracks

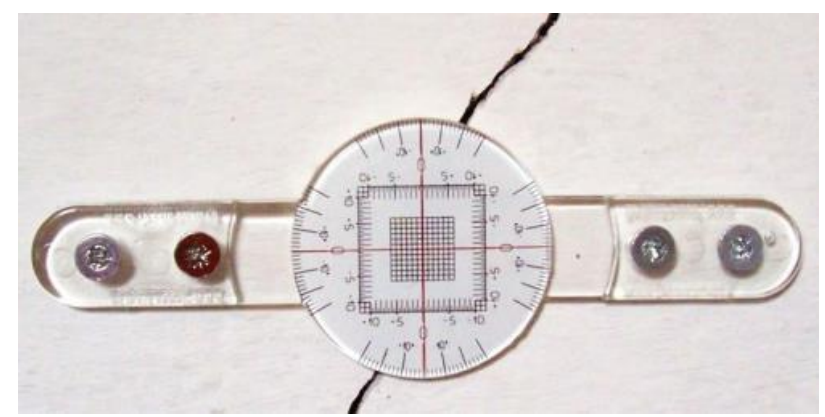

To solving the problem of presence of humidity it is suggested to decrease the contact surface of the walls with the ground after having adequately conveyed water away from the building and the surface.

To remove water from the perimeter walls we propose a drainage system.

'If the architect responsible for the restoration of a building needs to know the shapes, the styles of this building and the school from which it has come out, it is even better if it is possible to know its structure, its autonomy, its temperament, because first of all you have to live it.' - (Viollet Le Duc, 1854) 
The first method consists of excavation on the left side of the foundation, to put at the base, a drainage pipe that collects water and conveys it in a controlled discharge. The excavation is filled with drainage material.

Another solution consists of constructing a gap like a trench. In this way, it is easier for the evaporation of water in the masonry, possibly absorbed by capillarity by the foundations. It is necessary to have a space of $40-50 \mathrm{~cm}$ to construct an effective gap. It is also important that the cavities are ventilated to ensure the air circulation and permit the elimination of moisture that evaporates from the wall. Even if expensive, this technique is one of the most effective ways to protect the walls of new buildings from contact with water. In our case, in a building with ancient foundations, the addition of this system is particularly complicated and invasive due to the presence of grid or metal flashing along the perimeter of the church. For these reasons, between the two drainage methods proposed, the first is preferable.

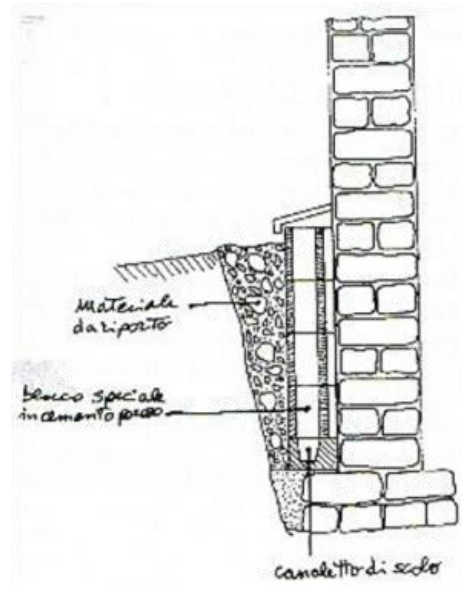

To perform the best removal of the water, it is proposed to redo the waterproofing layer bitumen (recommended thickness: at least $4 \mathrm{~mm}$ ) already present at the base of the facade on the northeast and to arrange the stones in a protective sheath.

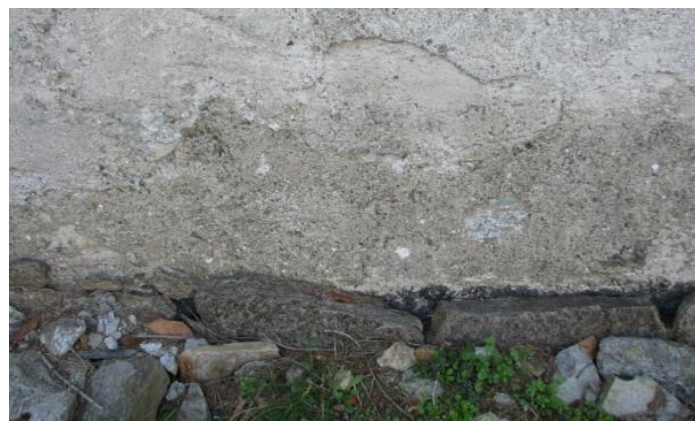

Figure 11. Scheme of two drainage methods

Figure 12. The western masonry of the Church 
It is experimentally verified that for walls with a thickness ranging between 40 and $80 \mathrm{~cm}$, as it is in this case, passive methods (waterproofing associated with drainage) decrease up to $2 / 3$ the surface contact between building and ground.

\section{CONCLUSION}

Architecture is an expression of cultural identity and the traceability of a historic building shouldn't have to be perceived as a problem, it can be considered an opportunity to learn the past to conserve and to emphasis on to pass on to the next generations with an increased economic value as well.

This paper describes the methodology implemented on the main façade of the Saint George church, which is a part of the project of conservation and rehabilitation of the whole church and the landscape surrounding it in the village of Mondonico (Rosina, 2017).

A SWOT (strengths, weaknesses, opportunities and threats) analysis flags off the process of strategic planning for the village, aiding the proposal for the possible re-use and revitalization of the historic church and the other buildings included in the project with the possibility to accentuate the collective memory of the past related to the church and the landscape surrounding it, resulting in the idea of a museum with the aim to give the users an experience of the past. The next phase of execution involved obtaining the permissions, which would include all the plans, elevations, sections and technical details of the whole building. Later Different technologies have been used to identify and analyze the problems in the building to propose appropriate interventions which are problem specific and are more effective and prevent problems that general interventions would cause in the future. One such problem to be identified is the rising damp in the church of St' George and appropriate interventions have been discussed.

The aim of this work is sensitize the designer to the historical value and include meticulous analysis of the present condition of the historic building to be able to conserve it better and transmit the historic significance to the next generations. This is done explained a methodology of conservation that enables us to understand the significance of the history of a monument and valorizes the use of local materials and building techniques, enhancing the potential of the project with an emphasis on the stimulus to the economic development. This methodology can be exported to other scenarios to be able to protect the built heritage in other contexts as well. 


\section{REFERENCES}

ACAM, State Archive of Milan, Notarile, cart. 5621.

Andreani, C. (1898). La Pieve di Dervio. Lecco, Tipografia Editrice Fratelli Grassi.

Angeli, F. (2001). Restauro architettonico. Padri, teorie, immagini. ISBN: 9788820431839.

Bellini, A. (1994). Teorie del restauro e conservazione architettonica, in A. Bellini, Tecniche della conservazione. Milano: Franco Angeli.

Cavada, E. e Gentilini, G. (2002). Il progetto di restauro architettonico. Dall'analisi all'intervento. Atti del seminario in Archeologia dell'Architettura. Trento: Palazzo Geremia.

Carbonara, G. (1996). Trattato di restauro architettonico, vol. III. Torino: UTET Press.

Della Torre, S. (2010). Conservazione programmata: i risvolti economici di un cambio di paradigma. Il capitale culturale. Studies on the Value of Cultural Heritage, pp. 47-55. Macerata: EUM Edizioni Università di Macerata.

Docci, M. (1999). Gli strumenti di conoscenza per il progetto di restauro in Seminario internazionale di studi a Valmontone. Roma. ISBN 9788849205114-8849205112

Rosina, E. (2017). Unravelling Mondonico: from the history towards a new future for the neglected village. ISBN: 9788864930398.

\section{Resume}

Francesca Andrulli was born in Italy. She is a tutor of the Architectural Restoration course at Politecnico di Milano, and she is a BIM construction engineer specialized in energy efficiency, mechanical design on both new and historic buildings.

Chiara Bonaiti was born in Italy. She is a Tutor of Restoration class at the School of Building Architecture and Engineering at Polytechnic of Milan in Lecco. She is an Engineer specialized in energy efficiency and building renovation. She's a member of Association of Engineers in Lecco.

Alessia Silvetti is an adjunct professor of Conservation Studio at the international Master Architectural Engineering Polytechnic of Milan in Lecco, and adjunct professor of Restoration Studio at the School of Building Architecture and Engineering, Polytechnic of Milan in Lecco. She has been Tutor (2009-2016) of Restoration + studio classes at the School of Building Architecture and Engineering, and Tutor (2012-2016) of Conservation + studio classes at the international Master Architectural Engineering and Polytechnic of Milan in Lecco. She's received "Tangram of Architecture 2004" in an Italian National Competition. She's interested in intervention of conservation and her focus on the 
Francesca Andrulli \& Chiara Bonaiti \& Alessia Silvetti

historical buildings and visual quality assessment in landscape architecture. She's a member of National Bioarchitecture Institute section of Lecco. 